\title{
Crossed Aphasia after Intracranial Hematoma in the Right Temporoparietal Lobe: A Case Report
}

\author{
Ju-Yeon Kim ${ }^{a}$, Won Kee Chang, ${ }^{\mathrm{a}, \mathrm{b}}$, Won-Seok Kim ${ }^{\mathrm{a}, \mathrm{b}}$ \\ ${ }^{a}$ Department of Rehabilitation Medicine, Seoul National University Bundang Hospital, Seongnam, Korea \\ ${ }^{b}$ Department of Rehabilitation Medicine, Seoul National University College of Medicine, Seoul, Korea
}

Correspondence: Won-Seok Kim, MD Department of Rehabilitation Medicine, Seoul National University Bundang Hospital, 82 Gumi-ro 173beon-gil, Bundang-gu, Seongnam 13620, Korea Tel: +82-31-787-7735

Fax: +82-31-787-4051

E-mail: wondol77@gmail.com

Received: October 1, 2021

Revised: November 1, 2021

Accepted: November 10, 2021
Purpose: Aphasia in a dextral after right hemisphere injury is called crossed aphasia (CA). We are reporting a first case of transformation of motor aphasia to conduction aphasia after right hemisphere intracerebral hemorrhage $(\mathrm{ICH})$ associated with arteriovenous malformation (AVM) with literature reviews. Methods: A case of a man in his 30s with CA following right hemisphere $\mathrm{ICH}$ in the temporal-parietal lobe associated with AVM was reviewed. We analyzed his brain images, initial linguistic characteristics, and changes in aphasia for 8 weeks of follow-up. Results: The initial Paradise Korean Western Aphasia Battery Revised (PK-WAB-R) was evaluated as aphasia quotient (AQ) 72, 64\%ile; post evaluation was evaluated AQ 95, 98.9\%ile after 8 weeks. The post-test repetition score was the patient score range, which can be attributed to impairment in phonological short-term memory. The patient is diagnosed anomalous CA based on Alexander et al., and we could predict that the language ability originates from both hemispheres based on Nagaraja et al. Considering the appearance of Gerstmann syndrome at the beginning of the onset, we could expect that the function of the dominant parietal lobe is partially crossed as well. Conclusion: Changes in aphasia were reported throughout the initial stage to the end of speech therapy. It is also important to note that literature review of Korean studies was analyzed in this study. It will be necessary to conduct a cognitive test in the early stage of onset to understand the language problems of crossed conduction aphasia to know the characteristics of the cognitive process.

Keywords: Conduction Aphasia, Crossed Aphasia, Cerebral Hemorrhage, Right Hemisphere 실어증(aphasia)은 보편적인 언어 습득 시기인 6세에서 9세가 지 난 후에 뇌손상으로 인하여 후천적으로 생기는 언어장애를 말하 며 뇌혈관 질환(cerebrovascular accident, CVA)이 가장 흔한 원인 이다. 실어증을 진단하기 위해서는 손잡이 정보가 매우 중요한데, 손잡이 정보는 언어중추가 어느 쪽 뇌의 반구에 위치하는지를 간 접적으로 시사하기 때문이다. 언어중추는 오른손잡이의 경우 대 부분 좌반구에 위치한다. 그런데 오른손잡이 환자가 우반구 손상 으로 인해 실어증의 증상을 보인다면 그 환자의 언어중추는 우반 구에 있을 수 있다. 이때 발생하는 실어증을 교차 실어증(crossed aphasia, CA)이라고 한다. CA는 우세한 손(dominant hand)과 같 은 쪽의(ipsilateral) 대뇌 반구 병변으로 실어증이 발생하는 것을 의
미하며, Bramwell (1899)이 처음 정의하였다. 그러나 이후 왼손잡이 에서도 좌반구에 언어중추가 위치하는 경우가 많다는 것이 밝혀지 면서 오른손잡이에서 우반구의 병변으로 발생하는 실어증에 한해 서만 CA의 정의가 사용되어 왔다(Mastronardi et al., 1994). 현재까 지 보고된 바에 의하면 출현율이 $.38 \%$ 에서 $3 \%$ 사이이며 그 빈도가 매우 드문 것으로 알려져 있다(Kim, Yang, \& Paik, 2013).

국내에서 발표된 $\mathrm{CA}$ 의 증례 보고는 총 9편, 기타 연구 논문은 총 3 편이 있는 것으로 확인하였다. 상기 12 편의 논문에서 보고된 CA 환자수는 모두 19명으로 CA의 양상은 전체 실어증(global aphasia) 8명, 베르니케 실어증(wernicke's aphasia) 2명, 전도성 실어증 (conduction aphasia) 1명, 연결피질운동실어증(transcortical mo- 
tor aphasia) 4명, 명칭 실어증(anomic aphasia) 1명으로 확인하였 다. 논문에서 비유창성 실어증(nonfluent aphasia)으로 보고된 증 례는 모두 운동성 실어증(motor aphasia)에 포함하여 총 3명으로 확인하였다. 이 중 17 명은 CA의 원인이 허혈성 뇌졸중(ischemic stroke)이고, 2명은 출혈성 뇌졸중(cerebral hemorrhage)이었다. 각 논문에서의 환자 특징은 Appendix 1에 요약하였다.

지금까지 보고된 국내의 CA 증례는 대부분 뇌혈관 폐색의 원인 으로 $\mathrm{CA}$ 가 발생하였고, $\mathrm{CA}$ 의 언어적 특징에 대한 기술보다 의학 적인 임상 정보를 중심으로 기술되었다. 두 편의 연구에서 뇌내출 혈(intracerebral hemorrhage, $\mathrm{ICH}$ ) 후 발생한 $\mathrm{CA}$ 를 보고하였는 데, $\mathrm{CA}$ 의 유형은 전체 실어증에서 브로카 실어증으로 변한 유형과 전도성 실어증 유형이었다. 그러나 상기 두 연구의 목적이 CA 중심 의 보고가 아니었고, 환자의 언어적 특징을 자세히 파악하기에 한 계가 있었다. 따라서 본 연구에서는 국내에서 처음으로 30대 남자 환자가 뇌동정맥기형(arteriovenous malformation, AVM)으로 인 해 $\mathrm{ICH}$ 가 발생하여 발병 초기에 운동성 실어증의 양상을 보였으나 전도성 실어증으로 그 유형이 변한 증례를 $\mathrm{CA}$ 의 언어적 특징, 실어 증의 변화를 중심으로 약 8주간 추적 관찰하여 MRI, Brain CT 소 견 및 문헌 고찰과 함께 보고하고자 한다.

본 연구는 분당서울대학교병원 생명윤리심사위원회(IRB No. B-2106-693-701)의 승인 및 연구 대상자의 사전 동의 면제를 받았다.

\section{연구방법}

환자는 35세 남자로 학력은 고등학교 졸업, 게임 관련 회사에서 업무를 해왔으며 과거에 기저 질환 없이 건강하게 생활하였다고 한 다. 에딘버러 손잡이 목록(Edinburgh Handedness Inventory) 문 항을 상세하게 확인하지 않았지만 환자와 보호자에게 환자가 왼손 으로 수행하는 동작이 있는지에 대해 질문하였을 때 없다고 하였 으므로 오른손잡이일 것으로 사료된다. 가족 중에 어머니가 왼손 으로 젓가락질을 할 수는 있지만 거의 사용하지 않으며, 오른손잡 이나다름없다고 보고하였다.

환자는 내원 5일 전부터(2020년 9월 24일) 두통, 실어증이 발생 하였고 기운 없음을 호소하였다. 보호자는 실어증이 발생한 당시 에 환자가 단어도 전혀 표현하지 못하였다고 보고하였다. 타병원에 먼저 방문하였으나 상급종합병원으로 의뢰되어 본원 응급실에 내 원하였고(2020년 9월 29일), 당시 검진상 운동성 실어증 이외의 신 경학적 증상은 없었으며 의식 상태는 명료하였다. 내원 1 일 차에 시 행한 Brain CT 검사상, 우측 측두엽에 많은 양의 뇌출혈(a large $\mathrm{ICH}$ in the right temporal lobe), 정맥 동맥류의 확장(venous aneu- rysmal dilatation), AVM과 연관된 뇌출혈이 발견되었고(Figure 1), 두개강내 동맥에서의(intracranial arteries) 협착(stenosis)은 없었 다. 이에 환자는 신경외과로 입원하였고 이후의 입원 경과는 다음 과 같다. 내원 2일차에 시행한 경대퇴뇌동맥 혈관조영술(Trans Femoral Cerebral Angiography, TFCA)에서 AVM이 우측 전두엽측두엽-두정엽에서의 파열로 인한 뇌출혈(AVM rupture, ICH on Rt. Frontal-Temporal-Parietal)이 관찰되었고, 병소의 크기는 25.2 $\times 19.6 \times 20.6 \mathrm{~mm}$ 인 것으로 나타났다. 내원 3 일차에 좌측 팔 저림 증상, 좌측 다리 감각 저하 및 저림 증상을 호소하였으나 호전 중이 라고 보고하였고, 내원 4 일차에 말하는 것은 많이 좋아졌다고 보고 하였다. 내원 8일차에 평가한 한국형 간이정신상태검사(KoreanMini Mental State Examination, K-MMSE; Kang, 2006)에서 27/30점을 획득하였는데, 오반응한 문항은 지남력의 '일, 요일', 언 어능력의 '따라 말하기' 문항이었다. 이름대기 문항에서 오류가 있 었지만 스스로 수정하였고, 계산 문항에서 응답을 구어로 하면 오 반응이지만 쓰기로 하면 정반응이었다.

언어치료는 내원일 기준 2 주차부터 시행하여 7주 동안 총 12 회 진행하였다. 환자는 일주일간 입원 후 자택으로 퇴원하였고, 이후 통원치료로 진행하였다. 실어증적 양상을 일관적으로 기술하기위 해 본원 응급실 내원일을 기준으로 작성하였다. 언어치료의 목표는 산출 측면에서 담화 전달, 문장 수준의 따라 말하기, 단어 인출, 담 화 쓰기였고, 이해 측면에서 담화 듣기 및 읽기였다. 쓰기는 충분한 시간이 소요되는 과제로 대부분 가정 과제를 통해 연습을 병행하 였으며, 치료 시간에는 말 산출과 단어 인출 증진을 중심으로 진행 하였다. 설명 담화, 절차 담화, 이야기 담화 등의 여러 가지 담화를 활용하여 전반적인 과제를 구성하였다. 초기 평가 결과를 바탕으

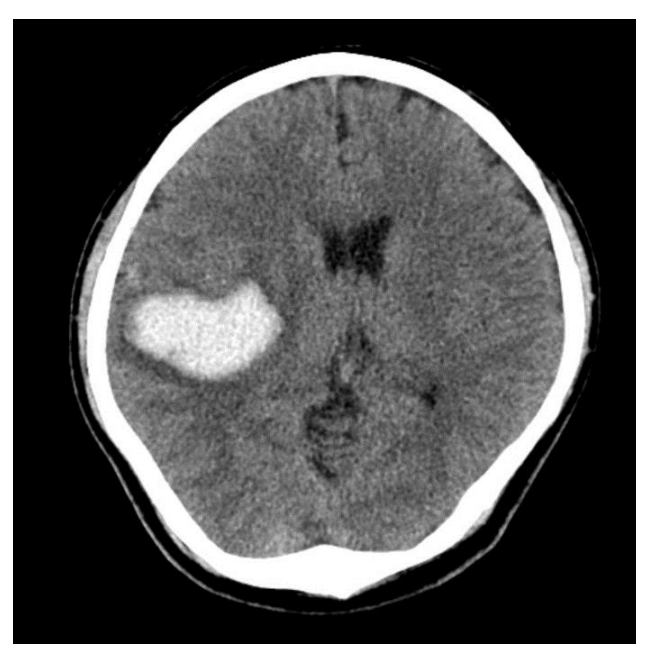

Figure 1. Brain CT. Acute ICH at right temporoparietal lobe with midline shifting to left. 
로 치료의 기초선을 확립하는 것이 필요하나 빠르게 회복되는 급성 기 단계의 환자였으므로 언어의 기능이 변하는 것을 중심으로 변 화의 정도를 기록하였다(Kim, 2021). 초기 평가의 결과는 Appen$\operatorname{dix} 2$ 에 제시하였고, 치료의 목표, 내용, 환자의 특징 등은 Appen$\operatorname{dix} 3$ 에 요약하였다.

내원일 기준 9주차에 초기 평가와 동일한 언어검사로 사후 평가 를 실시하였고, 전반적인 점수가 유의하게 향상된 것으로 나타났 다. 본 환자의 연령과 교육년수를 고려하였을 때 알아듣기, 이름대 기, 읽기, 쓰기는 정상군의 범주에 속하는 것으로 나타났다. 스스로 말하기는 표준편차에서 .03의(교육년수 7년 이상, 연령 15-64세 기 준 정상군의 평균 점수 19.68 , 표준편차 .65) 차이로 표준편차 이하 에 포함되었다. 그러나 따라 말하기의 경우 원점수 85 점, 백분위수 $66.43 \% \mathrm{ile}$ 로 여전히 환자군에 속하였다. 사후 평가의 각 영역별 원 점수, 백분위수, 언어 특징은 Appendix 4에 요약하였다.

\section{연구결과}

본 증례는 오른손잡이 환자가 우측 대뇌 반구의 출혈 후에 운동 성 실어증 유형의 CA가 발생한 보고이다. 응급실 내원 5 일전부터 시작된 실어증 양상에 대한 보호자의 보고와 초기 응급실 내원 당 시 의료진의 선별적인 판단 하에 운동성 실어증으로 보고되었다. 그러나 초기 언어평가를 실시하였을 때는 전도성 실어증으로 진단 되었으며, 추측하건데 초기 언어평가를 시행하기까지의 기간동안 언어기능은 일부 자연회복 되었을 것으로 사료된다. 총 치료 기간 은 7주였고, 치료 목표는 산출 측면에서 담화 전달, 문장 수준의 따 라 말하기, 단어 인출, 담화 쓰기였으며, 이해 측면에서 담화 듣기 및 읽기였다. 초기에도 청각적 이해력은 거의 보존된 수준이었으나 평 가 과제보다 더 상위 난이도의 담화 수준을 듣고 이해하는 것을 목 표로 진행하였다. 내원일 기준 3주차까지는 따라 말하기가 매우 어 렵고, 스스로 말하기에서도 발화는 유창하게 하는 듯하지만 음소 착어, 대용어, 간투사 등의 사용이 반복되는 등 완성형의 문장 발 화는 적었다. 그러나 4 주차 이후부터 완성형의 문장 산출이 증가하 기 시작하였고, 어떤 발화에서는 착어가 없는 문장을 산출하기도 하였다.

내원일 기준 9주차에 사후 평가를 실시하였고, 환자의 연령과 교 육년수를 고려하였을 때 알아듣기, 이름대기, 읽기, 쓰기는 정상군 의 범주에 속하였다. 스스로 말하기는 표준편차에서 .03의(교육년 수 7년 이상, 연령 15-64세 기준 정상군의 평균 점수 19.68 , 표준편 차 .65) 차이로 표준편차 이하에 포함되었으나 전반적인 과제 수행 의 정도를 질적으로 평가하면 거의 정상 범주에 속하는 것으로 판
단할 수 있다. 그러나 따라 말하기의 경우 원점수 85 점, 백분위수 66.43\%ile로 환자군에 속하였다. Ha, Hwang과 Pyun (2012)은 따 라 말하기의 결함이 구어 단기기억 손상에 의한 것으로 볼 수 있지 만 구어 단기기억 처리과정을 다차원 구어 단기기억의 측면에서 세 분화하여 살펴보는 것이 필요하다고 하였다. 다차원 구어 단기기억 처리과정에서 보면 따라 말하기는 음운적 통로(phonological short term memory, 음운단기기억)와 어휘-의미적 통로(lexico-semantic short term memory, 의미단기기억)로 구분하고, 음운적 통로는 음 운입력완충기(phonological input buffer)와 음운출력완충기(phonological output buffer)로 나눌 수 있다. 본 환자는 초기부터 언어 이해력에는 거의 문제가 없고, K-MMSE (Kang, 2006) 검사상으로 도 이해를 요구하는 과제에서의 오류는 없었기 때문에 의미단기기 억은 보존되어 있을 것으로 추측할 수 있다. 그러나 초기에 심각한 따라 말하기의 오류가 있었고, 중재 후에도 오류가 지속된 점을 고 려하면 음운단기기억상의 손상이 있음을 예측할 수 있다.

Joanette, Puel, Nespoulos, Rascol과 Lecours (1982)는 CA의 진단 기준으로 환자 및 가족력에서 왼손잡이나 양손잡이가 없을 것, 우 측 대뇌 반구에만 병변이 있을 것, 과거에 신경학적 병력이 없을 것, 실어증의 증상이 뚜렷할 것, 뇌의 기능적인 구조형성에 영향을 미치 는 환경적 요소가 없을 것 등 상기 5 가지의 기준을 제시하였다(Jo \& Park, 1997; Joanette et al., 1982; Primavera \& Bandini, 1993). 환자 는 오른손잡이이고, 가족력 중 어머니가 왼손으로 젓가락질을 할 수는 있으나 오른손잡이나 다름없다고 보고하였다. 이는 양손잡이 로 보기 어려워 상기 기준의 첫 번째 조건을 충족한다고 보았다. 환 자는 발병일에 $\mathrm{AVM}$ 을 진단받았지만 이전까지 기타 신경학적 병력 이나 AVM으로 인한 병력이 없었기 때문에 기준에 충족한다고 보 았다. 이하 3 가지의 기준도 모두 충족하여 CA로 진단하였다.

현재까지도 CA의 발생에 대한 정확한 원인이 밝혀진 바가 없고, 많은 가설들이 제시되고 있는데 그 중 가장 먼저 언급되는 것이 $\mathrm{Al}-$ exander, Fischette와 Fischer (1989)의 가설이다. Alexander 등 (1989)은 CA의 발생에 대해 병변의 위치와 실어증의 증상 사이의 연관성을 고려하여 두 가지 유형으로 설명하였다. 첫째, 거울상 (mirror image)은 좌반구의 언어중추에 대칭되는 우반구의 병소에 따라 좌반구의 병소에서 나타날 수 있는 실어증 양상과 동일한 양 상이 발생하는 것을 의미한다. 거울상은 모든 언어기능이 우뇌에 편측화되어 있다고 본다(Primavera \& Bandini, 1993). 모든 언어기 능이 우뇌에 편측화되어 있어 초기 실어증의 중증도가 심하고, 문 해능력이 저하되며, 회복 속도가 느려 비교적 심한 실어증적 증상 이 남게 된다. 때로는 우성 두정엽의 기능도 완전히 교차되어 거스 트만 증후군(Gerstmann syndrome)이 나타나기도 한다(Mastro- 
nardi et al., 1994). 거스트만 증후군은 우성 두정엽의 손상으로 실 산증(dyscalculia), 실서증(dysgraphia), 좌우지남력장애(right-left disorientation), 손가락 실인증(finger agnosia)의 증상이 발생하는 증후군을 뜻한다. 둘째, 비정형(anomalous)은 좌반구의 언어중추 위치로 유추하기 어려운, 정확한 원인을 예측할 수 없는 유형이다. 비정형은 실어증의 중증도가 경하고, 때로는 일시적이기도 하며 문 해능력은 스스로 말하기, 청각적 이해력보다 상대적으로 덜 손상 되고, 우성 측두엽의 기능도 보존되는 특징을 보인다.

한편 Nagaraja 등(1989)도 두 가지 유형의 CA를 제시하였다. 첫 째, 언어능력이 양측 반구 모두에 존재하며 이때의 실어증 증상은 경미하거나 일시적이고, 말과 쓰기의 손상 정도에도 차이가 있는 유형이다. Zangwill (1979)은 쓰기 능력이 보존된 반면 언어 표현은 심하게 손상된 증례를 발표하였고, Assal, Perentes와 Deruaz (1981)는 우반구 손상 후에 전체 실어증이 발생하였으나 좌반구 손 상 후에 발생한 전체 실어증과는 대조적으로 회복이 빠르고, 회복 후에도 심한 쓰기 장애가 남아있는 사례를 보고하였다. 이들은 CA 의 회복이 빠른 이유가 언어 산출(language production) 측면에서 말하기와 쓰기의 기능이 각기 다른 대뇌 반구의 명령을 받을 가능 성과 양쪽 대뇌 반구가 모두 언어 활동에 개입할 가능성을 제시하 였다. Jason과 Henry (1976)는 이를 언어의 양측 편측화(bilateral representation of language)라고 설명하였다. 언어의 양측 편측화 란 언어의 구성요소인 말하기, 듣기, 읽기, 쓰기의 기능을 담당하는 부분이 좌뇌와 우뇌로 분산되어 있는 것을 말한다(Alexander \& Annett, 1996; Jason \& Henry, 1976). 따라서 CA의 증상이 경하고 회복이 빠른 원인은 양측 대뇌 반구가 모두 언어 활동에 관여하기 때문인 것이다(James, 1986). 둘째, 언어능력이 우반구에만 존재하 며 이때의 실어증 증상은 매우 심하고, 회복도 불완전하며 읽기 및 쓰기능력도 같은 정도로 손상되는 유형이다. Cappa 등(1993)은 교 차 뇌량의 기능해리(cross-callosal diaschisis)에 의한 기능적 신경 학적 분리 현상 때문에 실어증의 증상이 매우 심하고 회복도 불완 전하다고 하였다.

본 증례의 환자에서 나타난 언어적 특징은 Alexander 등(1989) 의 제안에서 보면 비정형 교차실어증의 유형으로 판단된다. 발병 초기에 거스트만 증후군 중 손가락실인증을 제외하고 실산증, 좌 우지남력장애, 실서증이 있었던 것을 고려하면 우성 두정엽의 기능 도 부분적으로 교차되어 있음을 추정할 수 있다. 일반적으로 오른 손잡이에서 우반구는 시공간능력, 주의력 등에서 더 우세한 것으 로 알려져 있다. 본 환자의 경우 우반구 손상 후에 실어증과 거스트 만 증후군의 일부가 확인되었고, 시공간능력 및 주의력 등에는 문 제가 없었으므로 언어기능과 시공간능력이 다른 반구에서 그 기능
이 분리되어 있을 것으로 예측할 수 있다. 좌측 무시, 운율, 감정, 정 서기능 등의 기타 인지적 문제는 관찰되지 않았다. Nagaraja 등 (1989)의 제안에서 보면 본 환자는 언어능력이 양측 반구 모두에 존 재하는 것으로 짐작할 수 있다. 병소의 크기에 반해 환자의 실어증 중증도가 초기에는 중등도의 운동성 실어증이었으나 실어증 증상 이 시작된 시점을 기준으로 약 8 일 만에 경도의 유창성 실어증으로 변하였고, 발병 초기부터 언어이해와 읽기는 거의 보존되었으나 쓰 기와 말하기에서는 뚜렷한 실어증 증상이 있었으며, 7 주간의 언어 치료 후에 실어증 증상은 거의 회복되었기 때문이다. 그러나 실어 증 발병 후 2 개월 만에 빠르게 회복된 것은 시기적인 관점에서 보면 뇌손상의 초기인 급성기(acute phase) 단계에서 기능적으로 손상 된 부분이 정상화되면서 해리(diaschisis)로부터 회복되어 뇌기능 이 자연적으로 회복되었을 가능성이 있다(Kim, 2021). 자연회복은 발병 후초기 6개월까지 그 속도가 빠른 것으로 알려져 있으며 신경 재활이 활발히 일어나는 이 시기에 언어치료를 함으로써 언어장애 의 호전이 더욱 촉진되었을 수 있다.

\section{논의 및 결론}

본 연구는 국내의 첫 보고로 30 대 남성이 AVM으로 우반구에 $\mathrm{ICH}$ 가 발생하여 거스트만 증후군의 일부를 동반한 CA가 발생하 였는데 초기에는 운동성 실어증의 양상이었으나 회복하면서 전도 성 실어증으로 변한 증례이다. 7 주간의 언어치료 후에 스스로 말하 기, 알아듣기, 이름대기, 읽기, 쓰기는 정상군의 범주에 속하는 수준 으로 호전되었으나 따라 말하기는 환자군에 포함되는 것으로 나타 났다. 국내의 선행연구에서 $\mathrm{ICH}$ 에 의한 $\mathrm{CA}$ 의 사례를 보고한 적은 있으나 발병 초기부터 언어치료를 종결하는 시점까지의 전반적인 과정, 거스트만 증후군의 유무, $\mathrm{CA}$ 의 운동성 실어증 유형에서 전 도성 실어증 유형으로 변화된 환자에 대한 보고가 제한적이었다. 따라서 본 연구는 언어병리학의 측면에서 $\mathrm{CA}$ 의 실어증적 변화를 구체적으로 관찰 및 보고한 점, 국내의 $\mathrm{CA}$ 보고에 대한 문헌 고찰 을 함께 제시한 점에서 의의를 찾을 수 있다.

다만 본 환자의 따라 말하기 수행력과 다차원 구어 단기기억과 의 관계를 초기부터 평가하여 주기적으로 확인하고, 초기에 기타 인지적 검사를 시행하지 않은 부분은 제한점으로 불 수 있다. 이러 한 과정을 거쳤다면 $\mathrm{CA}$ 에서 나타난 언어적 문제와 기저의 인지 처 리과정의 특성도 함께 파악하여 교차 전도성 실어증(crossed conduction aphasia; Atsushi \& Takashi, 1992)과 관련된 더 많은 정보 를 수집할 수 있었을 것이다. 또한 대부분의 상급종합병원은 급성 기 환자가 내원하여 집중적이지만 단기적인 재활을 시행하는 기관 
Ju-Yeon Kim, et al. • Crossed Aphasia, Conduction Aphasia, Cerebral Hemorrhage, Right Hemisphere

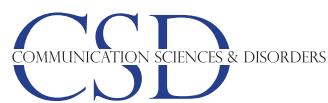

으로 종합적인 언어검사를 통해 치료의 호전 정도를 파악하기보다 간단하고 체계적인 표준화 검사가 개발되어 중재 과정에서의 주기 적인 평가를 진행해 객관적인 결과를 바탕으로 치료를 이어가는 것이 근거기반치료의 근거를 더욱 강화할 수 있을 것으로 사료된다.

\section{REFERENCES}

${ }^{*}$ indicates studies used for literature studies

Alexander, M. P., \& Annett, M. (1996). Crossed aphasia and related anomalies of cerebral organization: case reports and a genetic hypothesis. Brain and Language, 55(2), 213-239.

Alexander, M. P., Fischette, M. R., \& Fischer, R. S. (1989). Crossed aphasia can be mirror image or anomalous. Brain, 112(4), 953-973.

Assal, G., Perentes, E., \& Deruaz, J. P. (1981). Crossed aphasia in a righthanded patient: postmortem findings. Archives of Neurology, 38(7), 455458.

Atsushi, Y., \& Takashi, Y. (1992). A case of crossed conduction aphasia. Journal of Neurolinguistics, 7(3), 187-196.

Bramwell, B. (1899). On "crossed" aphasia and the factors which go to determine whether the "leading" or "driving" speech-centres shall be located in the left or in the right hemisphere of the brain: with notes of a case of "crossed" aphasia (aphasia with right-sided hemiplegia) in a left-handed man. The Lancet, 153(3953), 1473-1479.

Cappa, S. F., Perani, D., Bressi, S., Paulesu, E., Franceschi, M., \& Fazio, F. (1993). Crossed aphasia: a PET follow up study of two cases. Journal of Neurology, Neurosurgery \& Psychiatry, 56(6), 665-671.

${ }^{\star}$ Ha, J. W., Pyun, S. B., Hwang, Y. M., \& Sim, H. S. (2012). Lateralization of cognitive functions in aphasia after right brain damage. Yonsei Mecical Journal, 53(3), 486-494.

${ }^{\star}$ Han, S. H. (2011). A case presenting with crossed aphasia and gerstmann syndrome: an MR and SPECT imaging study. Chungbuk Medical Journal, 11(1), 76-82.

James, R. Y. (1986). Rapid recovery from crossed aphasia in a dextral. Archives of Clinical Neuropsychology, 1(2), 165-174.

Jason, W. B., \& Henry, H. (1976). Lateralization and language representation observations on aphasia in children, left-handers, and "anomalous" dextrals. Neurology, 26(2), 183-189.

${ }^{\star}$ Jo, Y. J., \& Park, K. H. (1997). Crossed aphasia in a dextral. Journal of the Korean Neurological Association, 15(2), 382-387.
Joanette, Y., Puel, M., Nespoulos, J. L., Rascol, A., \& Lecours, A. R. (1982). Aphasie croisee chez les droitiers. I. Revue de la litterature. Revue Neurologique, $138,575-586$.

Kang, Y. W. (2006). A normative study of the Korean-Mini Mental State Examination (K-MMSE) in the elderly. Korean Journal of Psychology, 25(2), $1-12$.

Kim, H. H., \& Na, D. L. (2012). Paradise Korean version of the Western Aphasia Battery Revised (PK-WAB-R). Seoul: Paradise Welfare Foundation.

${ }^{\star}$ Kim, H. S., Shin, J. B., \& Kim, J. M. (2011). Crossed transcortical motor aphasia, left spatial neglect, and limb and magnetic apraxia due to right anterior cerebral artery infarction. Annals of Rehabilitation Medicine. 35(6), 949-953.

${ }^{*}$ Kim, W. J., Yang, E. J., \& Paik, N. J. (2013). Neural substrate responsible for crossed aphasia. Journal of Korean Medical Science, 28(10), 1529-1533.

${ }^{\star}$ Lee, J. K., Kim, J. S., Kwon, S. A., Na, D. L., \& Son, Y. C. (1999). Crossed aphasia with severe left hemineglect following right hemispheric infarction in a dextral patient. Korean Journal of Stroke, 1(2). 246-250.

${ }^{\star}$ Lee, K. O., Na, S. J., Yum, K. S., Kim, J. E., \& Kim, Y. D. (2007). A case of dissociated crossed aphasia and anarthria in right hemispheric lesion. Konyang Medical Journal, 7(1), 84-86.

${ }^{\star}$ Lee, S. K., Kim, J. W., \& Ha, K. M. (1992). A case of crossed aphasia in a dextral. Journal of the Korean Neurological Association, 10(2), 219-223.

Mastronardi, L., Ferrante, L., Maleci, A., Puzzilli, F., Lunardi, P., \& Schettini, G. (1994). Crossed aphasia. An update. Neurosurgical Review, 17(4), 299304.

Nagaraja, D., Taly, A. B., Geetha, H., Rangamani, G. N., Shivashankar, N., \& Mukundan, C. R. (1989). Crossed aphasia in a dextral. Clinical Neurology and Neurosurgery, 91(2), 153-156.

Primavera, A., \& Bandini, F. (1993). Crossed aphasia: analysis of a case with special reference to the nature of the lesion. European Neurology, 33(1), 30-33.

${ }^{*}$ Rho, H. J., Kim, Y. W., Park, C. I., Park, J. B., \& Jang, J. H. (2007). Nonfluent crossed aphasia after right middle cerebral artery infarction-a case report. Journal of Korean Academy of Rehabilitation Medicine, 31(6), 772-775.

*Yoo, H. S., \& Kim, H. S. (2019). Crossed aphasia after right corpus callosum infarction: a case report. Brain and Neuro Rehabilitation, 12(1), 1-5.

Zangwill, O. L. (1979). Two cases of crossed aphasia in dextrals. Neuropsychologia, 17(2), 167-172. 
Appendix 1. Literature studies about crossed aphasia

\begin{tabular}{|c|c|c|c|}
\hline Author (year) & $\begin{array}{l}\text { Lesion of the brain } \\
\text { (Right hemisphere) }\end{array}$ & Purpose & $\begin{array}{l}\text { Characteristics of patients } \\
\text { A: age (yrs)/gender, education (yrs) } \\
\text { B: Initial AQ score, Initial aphasia type } \\
\text { C: summary }\end{array}$ \\
\hline $\begin{array}{l}\text { 1. Lee, Kim, \& Ha } \\
\text { (1992) }\end{array}$ & $\begin{array}{l}\text { Subcortical infarction in } \\
\text { the inferior F-T-P }\end{array}$ & Case report & $\begin{array}{l}\text { A: } 49 / M, 6 \\
\text { B: NI, Global aphasia } \\
\text { C: 알아듣기 거의 불가, 짧고 무의미한 단음절 발화 반복, 발병 } 5 \text { 개월 후에도 심한 실어증이 지속되었으 } \\
\text { 며, 발병 전후의 AQ점수는 제시되지 않았다. }\end{array}$ \\
\hline 2. Jo \& Park (1997) & $\begin{array}{l}\text { Subcortical infarction in } \\
\text { the F-T-P }\end{array}$ & Case report & $\begin{array}{l}\text { A: } 61 / F, N 1 \\
\text { B: NI, Global aphasia } \\
\text { C: 모든 영영에서 무반응, 단음절의 모음 산출 가능, 발병 } 42 \text { 일 후에도 심한 실어증이 지속되었으며, 발 } \\
\text { 병 전후의 AQ점수는 제시되지 않았다. }\end{array}$ \\
\hline $\begin{array}{l}\text { 3. Lee, Kim, Kwon, Na, } \\
\text { \& Son (1999) }\end{array}$ & Infarction in the T-P & Case report & $\begin{array}{l}\text { A: } 60 / M, 16 \\
\text { B: NI, Wernicke's aphasia } \\
\text { C: 실산증, 좌우지남력장애, 신체지남력장애, 시공간 기능 저하, 심한 좌측 편무시가 동반되었다. 입원 } \\
\text { 7일째부터 호전된 양상으로 말은 유창하나 단어 찾기의 어려뭄이 있었고, 발병 전후의 AQ점수는 제 } \\
\quad \text { 시되지 않았다. }\end{array}$ \\
\hline 4. $\operatorname{Han}(2001)$ & Infarction in the MCA & Case report & $\begin{array}{l}\text { A: } 70 / M, N 1 \\
B: N I, \text { Wernicke's aphasia } \\
\text { C: 입원 7일째부터 언어 증상의 호전이 관찰되었고, 입원 } 10 \text { 일째 K-MMSE 검사상 23/30점을 획득하 } \\
\text { 였느나 발병 전후의 AQ점수는 제시되지 않샀다. }\end{array}$ \\
\hline $\begin{array}{l}\text { 5. Rho, Kim, Park, } \\
\text { Park, \& Jang (2007) }\end{array}$ & Infarction in the MCA & Case report & $\begin{array}{l}\text { A: } 49 / M, 16 \\
\text { B: AQ } 50.4, \text { LQ 49.8, Nonfluent aphasia } \\
\text { C: 거르스트만 증후군이 동반되었지만 실행증, 무시증후군은 관찰되지 않았고, 발병 후 } 19 \text { 주째의 평가 } \\
\text { 에서 AQ 84.6, LQ 76.6으로 호전된 양상이었다. }\end{array}$ \\
\hline $\begin{array}{l}\text { 6. Lee, Na, Yum, Kim, } \\
\text { \& Kim (2007) }\end{array}$ & $\begin{array}{l}\text { Infarction in the MCA and } \\
\text { ACA }\end{array}$ & Case report & $\begin{array}{l}\text { A: } 82 / \mathrm{M}, \mathrm{NI} \\
\mathrm{B}: \mathrm{NI} \text { 해리성교차언어상실증(dissociate crossed aphasia) } \\
\text { C: 문장을 듣고 읽는 데는 비교적 문제없이 수해이 가능하나 언어의 산출 및 쓰기는 전혀 이루어지지 안 } \\
\text { 은 운동성 상실증의 양상이었으며 발병 전후의 AQ점수는 제시되지 않았다. 해리성교차언어상실증 } \\
\text { 용어를 처음 제시하였다. }\end{array}$ \\
\hline 7. Cho et al. (2009) & $\mathrm{ICH}$ in the STC and IPC & $\begin{array}{l}\text { Analyzing } \\
\text { neuroimage }\end{array}$ & $\begin{array}{l}\text { A: 54/F, } 12 \\
\text { B: AQ 63.2, Conduction aphasia }\end{array}$ \\
\hline 8. Baek et al. (2011) & Infarction in the MCA & Case report & $\begin{array}{l}\text { A: } 76 / M, 16 \\
\text { B: NI, Global aphasia } \\
\text { C: 발병 전에 무증상의 좌뇌 병변이 있었고, 좌측 무시가 동반되었으며 발병 후 } 10 \text { 일째까지도 전체 실 } \\
\text { 어증이 지속되었다. 발병 전후의 AQ점수는 제시되지 않았다. }\end{array}$ \\
\hline $\begin{array}{l}\text { 9. Kim, Shin, \& Kim } \\
\text { (2011) }\end{array}$ & Infarction in the ACA & Case report & $\begin{array}{l}\text { A: 70/F, NI } \\
\text { B: AQ 25.8, Transcortical motor aphasia } \\
\text { C: Left hand magnetic apraxia와 사지관념운동실행증을 동반하였고, 발병 7주 후의 평가에서 AQ } \\
\text { 48.6으로 호전되었다. }\end{array}$ \\
\hline $\begin{array}{l}\text { 10. Ha, Pyun, Hwang, } \\
\text { \& Sim (2012). }\end{array}$ & Infarction in the $\mathrm{ACA}$ & $\begin{array}{l}\text { Comparing } \\
\text { 3cases about } \\
\text { cognitive } \\
\text { functions }\end{array}$ & 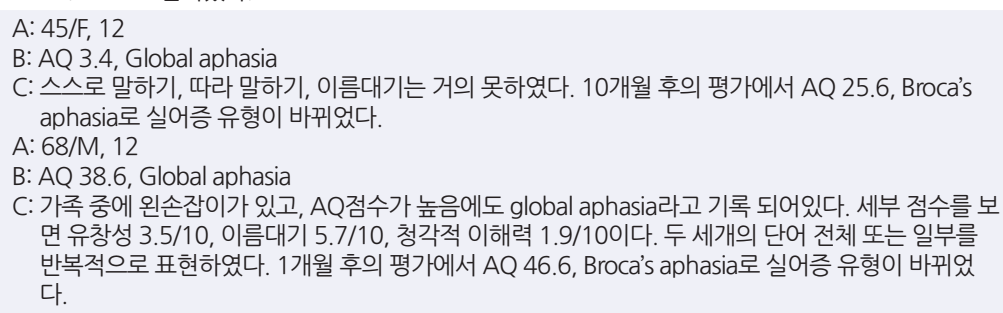 \\
\hline 11. Kim et al. (2013) & $\begin{array}{l}\text { Ischemic lesion in the P-T } \\
\text { Ischemic lesion in the } F \\
\text { and BG } \\
\text { Ischemic lesion in the P } \\
\text { Ischemic lesion in the } \\
\text { thalamus } \\
\text { Ischemic lesion in the BG } \\
\text { Ischemic lesion in the BG } \\
\text { and thalamus } \\
\text { Ischemic lesion in the } \\
\text { F-T-P }\end{array}$ & Lesion mapping & $\begin{array}{l}\text { A: } 76 / M, 6 \\
\text { B: AQ } 19, \text { Global aphasia } \\
\text { A: } 52 / F, 9 \\
\text { B: AQ 48, Transcortical motor aphasia } \\
\text { A: } 51 / F, 9 \\
\text { B: AQ 23, Motor aphasia } \\
\text { A: } 81 / M, 0 \\
\text { B: AQ } 14, \text { Global aphasia } \\
\text { A: } 70 / F, 0 \\
\text { B: AQ 58, Transcortical motor aphasia } \\
\text { A: } 70 / M, 0 \\
\text { B: AQ 78, Anomic aphasia } \\
\text { A: } 74 / M, 6 \\
\text { B: AQ } 37 \text {, Transcortical motor aphasia }\end{array}$ \\
\hline 12. Yoo \& Kim (2019) & Infarction in the CC & Case report & $\begin{array}{l}\text { A: 74/F, NI } \\
\text { B: AQ 2.5, Global aphasia } \\
\text { C: CA발병 전에 right thalamus infarction이 있었고 2차 뇌경색으로 CA가 발생하였다. }\end{array}$ \\
\hline
\end{tabular}

$\mathrm{AQ}=$ Aphasia quotient; $\mathrm{LQ}=$ Language quotient; $C A=$ Crossed aphasia; $K-M M S E=$ Korean-Mini Mental State Examination (Kang, 2006); $F=$ Frontal lobe; $T=$ Temporal lobe; $\mathrm{P}=$ Parietal lobe; $C \mathrm{C}=$ Corpus callosum; $\mathrm{MCA}=$ Middle cerebral artery; $\mathrm{BG}=$ Basal ganglia; $\mathrm{ICH}=$ Intracerebral hemorrhage; STC=Superior temporal cortex; $\mathrm{IPC}=$ Inferior parietal cortex; $\mathrm{NI}=$ No information 
Appendix 2. The results of Initial PK-WAB-R

\begin{tabular}{|c|c|}
\hline Category of PK-WAB-R & Initial score \\
\hline 1. Spontaneous speech (20) & 13 (51.82\%ile) \\
\hline Information content (10) & 8 \\
\hline Fluency (10) & 5 \\
\hline \multicolumn{2}{|c|}{ 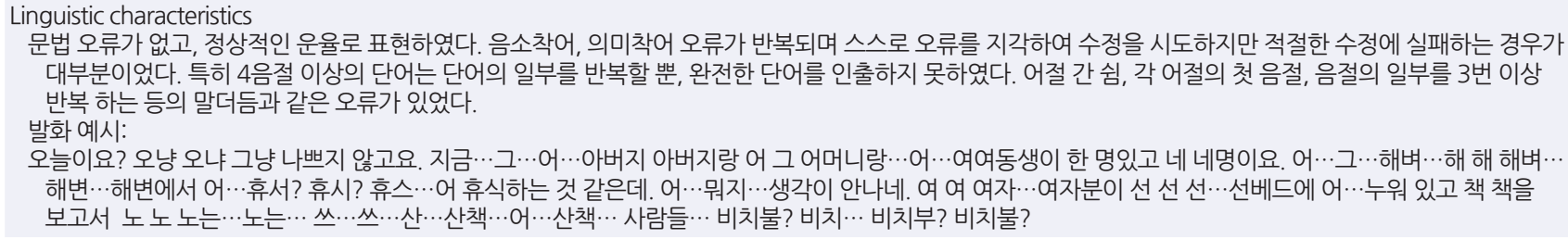 } \\
\hline 2. Auditory Comprehension (200) & 196 (98.02\%ile) \\
\hline Yes/no questions (60) & 60 \\
\hline Auditory word recognition (60) & 56 \\
\hline Sequential commands (80) & 80 \\
\hline
\end{tabular}

Linguistic characteristics

예/아니오 문항에서 '망치가 나무 자르는데 쓰여집니까, 구두를 신은 다음에 양말을 신습니까, 코끼리가 쥐보다 큽니까, 새가 벌레한테 잡아먹힙니까' 질문은 두 번 제시 후에 정반응 하였다. 그 외 알아듣기 과제는 즉각 수행하였고, 낱말 인지의 숫자 $(1867,5000)$, 좌우 지각(오른쪽 귀, 왼쪽 눈) 문항에서 오반응 하였다.

3. Repetition (100) 54 (39.83\%ile)

Linguistic characteristics

3음절 단어부터 음소착어가 있지만 스스로 수정이 가능하였다. 문장 수준이더라도 한 어절의 단어가 3음절 이내이면 정확하게 따라 말하거나 스스로 수정할 수 있지만 4음절 이상부터는 오류 수정에 실패하거나 일부 음절도 전혀 따라 말하지 못하였다. 문장 수준에서는 어절 생략 오류가 있었고, 문장의 길이가 길어질수록 오류를 지각하는 정확도도 낮아졌다. 이때 환자는 자주 ‘안 들린다, 뭔가 빠져서 들린다.’고 호소하였다.

발화 예시:

‘다람쥐’ $\rightarrow$ ‘다람기, 다람지, 다람쥐'

'다람쥐' $\rightarrow$ '다람기, 다람지, 다람쥐'

'겨우 잠이 들었다' $\rightarrow$ '겨우 어 $\cdots$ 즈 잠이 달아다'

'칼날같이 날카로운 바위' $\rightarrow$ '칼...날...같이 날까 날카로운 바 바 바리'

'아니 땐 굴뚝에 연기나랴' $\rightarrow$ '어 $\cdots$ 안 $\cdots$ 아나 $\cdots$ (생략) 분뚜 $\cdots$ 어 $\cdots$ (생략)'

'그러나 혹은 그런데 중에 택하시오' $\rightarrow$ '어 $\cdots$ 그 $\cdots$.어 $\cdots$ 모르겠어요'

‘스물일곱 개의 찬 맥주병이 냉장고에 있다’ $\rightarrow$ '어 $\cdots$ 서물 $\cdots$ 서물일곱 거 $\cdots$ 거 $\cdots$ 개의 (생략) 매 $\cdots$ 매구 $\cdots$ 맥주 $\cdots$ 맥주병 $\cdots$ 내 내 냉장 냉장기 $\cdots$ 냉장고에 어 어 이 $\cdots$ 있 $\cdots$ 있디...있다'

4. Naming (100)

Confrontation naming (60)

78 (79.55\%ile)

Generative naming (20)

49

Sentence completion (10)

11

Responsive speech (10)

8

10

Linguistic characteristics

물건이름대기에서 오반응 3 개, 음소착어를 동반한 정반응 2 개('젓가락' $\rightarrow$ '젓기락', ‘주사기’ $\rightarrow$ ‘주시기'), 음소착어가 있었지만 스스로 수정한 문항이 4 개 있었다.

통제 단어연상에서 3음절 이상의 단어를 인출할 때 음소착어 오류가 있었지만 스스로 수정하였고, 4음절 단어는 착어가 반복되다가 결국 단어인출에 실패하여 다른 단어로 인출하였다.

발화 예시:

'코끼리' $\rightarrow$ '코…코끄리 코끼리'

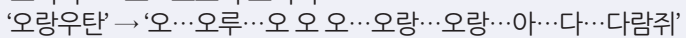

5. AQ (100)

6. Reading (100)

72 (64\%ile)

Linguistic characteristics

글 명령의 음독을 수행할 때 철자 오류가 각 어절마다 연속적으로 있었지만 모두 스스로 수정을 거듭하여 적절하게 읽었다.

발화 예시:

'손을 들어보세요' $\rightarrow$ '소 $\cdots$ 손을 $\cdots$ 드 $\cdots$ 들어 들이 들어보 $\cdots$ 세요'

'발로 십자가를 그려보세요’ $\rightarrow$ '발리 발 $\cdots$ 발로 시스 습 $\cdots$ 십자가 $\cdots$ 를 $\cdots$ 그 거 려 $\cdots$ 어 $\cdots$ 그려보 $\cdots$ 세요'

7. Writing (100)

83.5 (72.3\%ile)

Linguistic characteristics

스스로 쓰기(이름, 주소, 그림묘사, 숫자 등)에서는 철자오류가 주된 오류였고, 그림묘사에서는 철자오류와 문법오류가 함께 있었다. 받아쓰기(문장 받아쓰기,

단어 받아쓰기 등) 에서는 음소착어, 의미착어, 생략 오류 등의 오류가 있었다.

문장 예시:

스스로 쓰기: ‘오포읍’ $\rightarrow$ ‘오표읍, '금’ $\rightarrow$ '급' '세 명이 비치볼를 한다', '아빠가 아이들과 모래놀이를 한다', '여자가 의자에 앉아 책을 읽고 있다', '노 부부가 산책을 간다’ 받아쓰기: ‘호루라기' $\rightarrow$ ‘호루' '‘867’ $\rightarrow$ '1896' '맥주병이' $\rightarrow$ '맥주', '일곱 개의 찬 맥주병이’ $\rightarrow$ '아홉 개의 찬 맥주'

8. LQ (100)

$84.5(85.13 \%$ ile)

PK-WAB-R= Paradise Korean Western Aphasia Battery Revised (Kim \& Na, 2012); AQ = Aphasia quotient; LQ = Language quotient. 
Appendix 3. Speech therapy for 7 weeks

\begin{tabular}{|c|c|c|}
\hline Date & Goal & Linguistic characteristics \\
\hline 주차 & 1. 따라 말하기 & 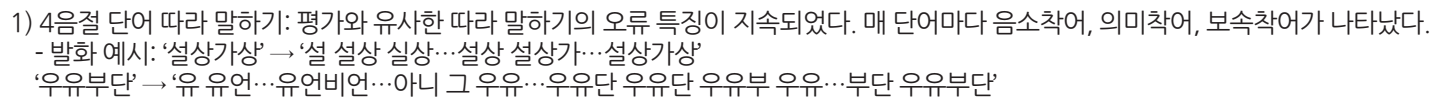 \\
\hline & 2. 담화 전달 & 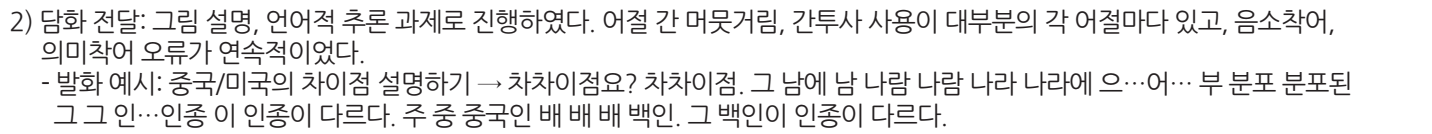 \\
\hline
\end{tabular}

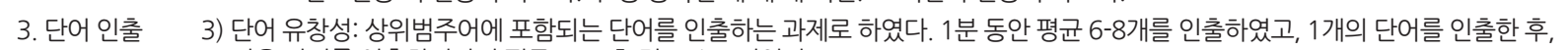
다음 단어를 인출하기까지 평균 9-12초 정도 소요되었다.

- 발화 예시: 오지 오이 오이 (9초) 양 양 양 양파 양파 (9초) 어 양 쓰양 아 바 양 양태 양 양배추. 양 양 양파했고 (12초) 깬 깬 깬깨... 깬 깻잎 아 깻잎

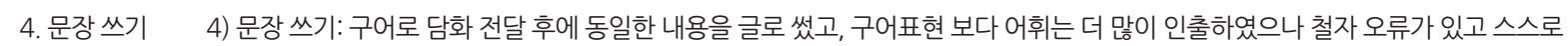
수정하지 못하였다.

- 쓰기 예시: '닦음' $\rightarrow$ ‘닫음'

5) 환자의 보고: 앞에 한 글자, 두 글자는 들리는데 뒤에는 안 들린다, 글자가 빠졌는데 몇 글자가 빠진 것인지 모르겠다, 음악을 들으면 음이 자꾸 빠지는 것 같다.

3 주차 1. 따라 말하기 1 1) 4음절 단어 따라 말하기: 2 주차와 동일한 단어 및 새로운 단어를 함께 진행하였다. 2주차와 거의 유사한 수준이었다.

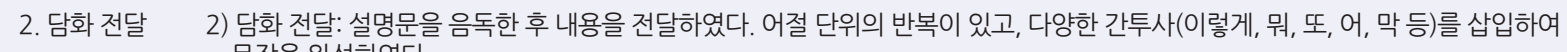
문장을 완성하였다.

- 발화 예시: 음 뭐 동수 뭐지 동 $\cdots$ 동물들이 뭐 어 사람들보다 먼저 $\cdots$ 어 강저, 재앙? 어 그 재앙? 재앙을 예측한다? 재앙을 예측 한다는 뭐 그런 내용...내용을 봤습니다.

3. 단어 인출 $\quad 3$ ) 단어 유창성: 2 주차와 동일한 주제 및 새 주제를 함께 진행하였다. 2주차와 동일한 주제는 12-13개, 새 주제는 11-12개 인출이 가능하였다.

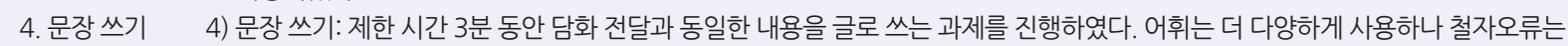
지속되었다. - 쓰기 예시: ‘골칫거리’ $\rightarrow$ ‘골차거리’, ‘많이’ $\rightarrow$ ‘만이’

4주차 1. 따라 말하기 1 1) 4음절 단어 따라 말하기: 3주차와 동일한 단어 및 새로운 단어를 함께 진행하였다. 연습한 단어는 정확히 따라 말할 수 있지만, 새로운 단어에서는 의미착어 오류가 있었다.

- 발화 예시: ‘인과응보’ $\rightarrow$ '인과응보', ‘차일피일’ $\rightarrow$ ‘차일피일', ‘유유자적’ $\rightarrow$ ‘유유자작 유유자적, ‘좌지우지’ $\rightarrow$ ‘좌 ‥지 ‥우지 좌우 좌지우지', '호시탐탐 $\rightarrow$ ‘호시탐정'탐탐 호시탐탐'

2. 담화 전달 $\quad$ 2) 담화 전달: 설명문을 음독한 후에 내용 전달하기, 그림 설명하기, 대화 등의 과제를 진행하였다. 대화에서의 내용전달과 유창성은 구조화된 과제보다 노력성이 적은 편이지만 반복적인 간투사의 사용이 나타났다.

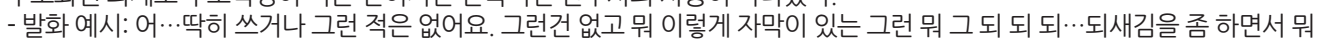
그런거는 조금 계속 하고 있었는데 워 그런 그런거는 문장 자체를 이해하는 게 엄청 느렸는데 이제 뭐 어느정도 그 뭐 이해가 나오는 대로 이해가 되는? 이해가 되는 것 같아요. 거의 뭐 백프로는 아니고요. 그 구십에서 구십 어 구십오프로? 정도 되는 것 같아요.

3. 단어 인출 $\quad 3$ ) 단어 유창성: 3주차와 동일한 주제 및 새 주제를 함께 진행하였다. 주제의 친숙도에 상관없이 1분 동안 평균 11-13개를 인출하였다.

5 주차 1 . 담화 전달 $\quad$ 1) 담화 전달: 2 분 길이의 뉴스를(TV로 방송된 저녁 뉴스 발췌) 듣고 이야기를 다시 말하는 과제를 하였다. 문장 길이 증가, 대용어 및 간투사 사용 감소에 중점을 두었다. - 발화 예시: 거 ․ㅡ리두기가 그 1 단계 행사를 한다고 했어요. 덕수 그 덕 $\cdots$ 수궁 덕수궁에서 사람들이 모여서 뭐 축제를 하고, 또 $\cdots$ 또 그 꽃 $\cdots$ 국 국화 국화 그 전시를 본다고 했어요. 그리고 또 뭐 조심하지만 마스크를 끼고 잘 이렇게 돌아다닌다고, 축제를 연다고 했어요.

$\begin{array}{ll}\text { 2. 단어 인출 } & \text { 2) 단어 인출: 유의어, 반의어를 찾는 과제를 중점적으로 하였다. 반응시간은 지연되지만 반의어 인출은 모두 정반응, 유의어 인출은 }\end{array}$ 음절 단서가 필요하기도 하였다. 음절 단서 후에는 정반응하였다.

6주차 $\quad$ 1. 담화 전달 $\quad$ 1) 담화 전달: 2 분 길이의 뉴스를(TV로 방송된 저녁 뉴스 발췌) 듣고 이야기를 다시 말하는 과제를 하였다. 5 주차와 동일하게 문장 길이 증가, 대용어 사용 감소에 중점을 두었다. 매 문장에서의 착어 오류, 대용어 사용이 거의 없지만 간투사(어, 그리고, 뭐였지, 또 등)는 지속적으로 나타났다.

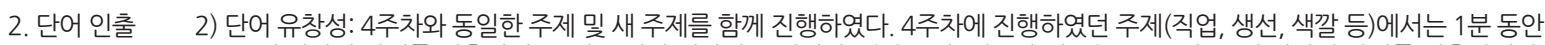
15 개 이상의 단어를 인출하였고, 새 주제인 제한된 주제에서도(매운 것, 네모난 것 등) 1 분 동안 10 개 이상의 단어를 인출하였다.

3) 환자의 보고: 컨디션에 따라 다르지만 말이 좀 빨리 되는 것 같고, 책 읽는 것도 빨라졌고, 단어를 다양하게 쓰는 것 같다.

7 주차 $\quad$ 1. 담화 전달 $\quad$ 1) 담화 전달: 2 분 길이의 뉴스를(TV로 방송된 저녁 뉴스 발췌) 듣고 이야기를 다시 말하는 과제를 하였다. 과제의 내용에 대한 친숙도가 낮은 주제를 중심으로 진행하였다. 평소에는 뉴스를 1 회만 들으면 대부분 내용이해가 가능하였는데 본 회기에서는 3 회를 들은 후 내용이해가 가능하였다.

2. 문장 쓰기 $\quad$ 2) 문장 쓰기: 동일한 뉴스를 30초만 듣고 내용을 도식화하며 요약하는 연습을 하였는데 핵심단어의 생략이 빈번하였다.

3) 환자의 보고: 저기압, 북부지방 이런 단어는 잘 안 들린다. 집중하면 겨우 한 두 글자 들리는 기분이다. 내용을 쓰는 것은 할 수 있는데 한 문장을 쓰는 중에 다음의 내용을 계속 잊는 것 같다.

8 주차 1 . 담화 전달 $\quad$ 1) 담화 전달: 2 분 길이의 뉴스를(TV로 방송된 저녁 뉴스 발췌) 듣고 이야기를 다시 말하는 과제를 하였다. 뉴스 도입부에서 앵커가 보도 내용을 요약하여 전달하는 부분을 $80 \%$ 이상 정확하게 다시 말하는 것을 목표로 진행하였다. 유창성 측면에서 대부분 오류가 없는 완전한 형태의 문장으로 산출할 수 있었다.

- 발화 예시: 그냥 친구들 좀 만나고 집에서 쉬고 그러고 있어요. 그 $\cdots$ 뉴스나 영화 자막보는거 그런 연습하고 있고요. 이제는 거의 뭐 다 되는 것 같아요. 저는 괜찮은데 어머니가 걱정하시니까 그게 좀 저도 마음이 그렇죠.

$\begin{array}{ll}\text { 2. 단어 인출 } & \text { 2) 단어 인출: 유의어, 반의어를 찾는 과제를 중점적으로 하였다. 반의어는 질문과 동시에 즉각 단어 인출이 가능하였고, 유의어는 반응 }\end{array}$ 시간이 필요하지만 치료사의 단서는 필요하지 않았다.

3) 환자의 보고: 컨디션 좋은 날에는 발병 전과 비슷하다. 음악도 이제 거의 잘 들린다. 
Appendix 4. The results of 8 weeks after onset of PK-WAB-R

\begin{tabular}{|c|c|}
\hline Category of PK-WAB-R & Initial Score \\
\hline 1. Spontaneous speech (20) & 19 (96.86\%ile) \\
\hline Information content (10) & 10 \\
\hline Fluency (10) & 9 \\
\hline \multicolumn{2}{|l|}{ Linguistic characteristics } \\
\hline \multicolumn{2}{|c|}{$\begin{array}{l}\text { 가끔 발화의 시작에서 머뭇거림이 있고, 발화 간의 간격도 있지만 유창하게 표현할 수 있었다. 간헐적인 낱말 찾기의 어려움, 음소착어의 오류가 있었다. } \\
\text { 발화 예시: }\end{array}$} \\
\hline \multicolumn{2}{|c|}{ 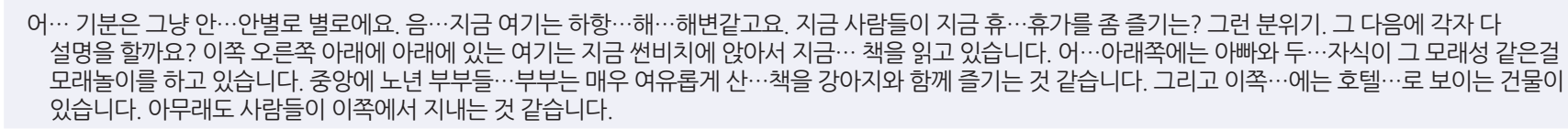 } \\
\hline 2. Auditory comprehension (200) & 200 (>99\%ile) \\
\hline Yes/no questions (60) & 60 \\
\hline Auditory word recognition (60) & 60 \\
\hline Sequential commands (80) & 80 \\
\hline 3. Repetition (100) & 85 (66.43\%ile) \\
\hline \multicolumn{2}{|l|}{ Linguistic characteristics } \\
\hline \multicolumn{2}{|l|}{$\begin{array}{l}\text { 4어절 이상의 } \\
\text { 4음절 이상 }\end{array}$} \\
\hline \multicolumn{2}{|l|}{ 발화 예시: } \\
\hline \multicolumn{2}{|c|}{ '그가 내 뒤를 몰래 밟았다' $\rightarrow$ '그가 내 뒤를 몰래 따라왔다' } \\
\hline \multicolumn{2}{|c|}{ '아니 땐 굴뚝에 연기나랴' $\rightarrow$ ‘아니 땐 굴뚝에 연가나랴' } \\
\hline \multicolumn{2}{|c|}{ '그러나 혹은 그런데 중에 택하시오' $\rightarrow$ '그러나 혹은 어 $\cdots$ 그 $\cdots$ 어 $\cdots$ 네 $\cdots$ (생략)' } \\
\hline \multicolumn{2}{|c|}{ ‘스물일곱 개의 찬 맥주병이 냉장고에 있다’ $\rightarrow$ ‘스물 $\cdots$ 한 개 병의 차가운 $\cdots$ 찬 맥주가 냉장고 안에 들어있다' } \\
\hline 4. Naming (100) & 100 (>99\%ile) \\
\hline Confrontation naming (60) & 60 \\
\hline Generative naming (20) & 20 \\
\hline Sentence completion (10) & 10 \\
\hline Responsive speech (10) & 10 \\
\hline \multicolumn{2}{|l|}{$\begin{array}{l}\text { Linguistic characteristics } \\
\text { 통제단어연상에서 ‘맷돼즈 }\end{array}$} \\
\hline 5. AQ (100) & 95 (98.9\%ile) \\
\hline 6. Reading (100) & 100 (>99\%ile) \\
\hline $\begin{array}{l}\text { Linguistic characteristics } \\
\text { 글 명령의 음독을 수행할 때 오류가 } \\
\text { 발화 예시: } \\
\text { '발로 십자가를 그려보세요' } \rightarrow \text { ‘발리 } \\
\text { '연필을 잡은 다음에 연필로 책상을 }\end{array}$ & 책상을 세 번 두드러 $\cdots$ 두드리고 다시 제자리에 놓으세요' \\
\hline 7. Writing (100) & 99 (>99\%ile) \\
\hline \multicolumn{2}{|c|}{$\begin{array}{l}\text { 문장 받아쓰기에서 ‘찬 맥주병’을 ‘차가운 맥주병’으로 쓰는 의미착어 오류가 있었다. 그림묘사는 8어절 이상의 복문을 다양한 단어로 구성하여 쓸 수 있었다. } \\
\text { 그림묘사의 문장 예시: 호텔이 있는 한 해변에서 사람들이 여유롭게 휴식을 즐기고 있습니다. 왼쪽에는 세 명의 사람들이 비치 발리볼을 즐기고 있습니다. 중앙에는 } \\
\text { 한 노부부가 여유롭게 산책을 즐기고 있으며, 반려견도 함께 따라 나온 것으로 보입니다. 아래쪽에서는 아빠와 두 아이가 모래를 이용해 놀(시간 종료). }\end{array}$} \\
\hline 8. LQ (100) & 97.3 (>99\%ile) \\
\hline
\end{tabular}

PK-WAB-R=Paradise Korean Western Aphasia Battery Revised (Kim \& Na, 2012); AQ = Aphasia quotient; LQ = Language quotient. 


\section{국문초록}

\section{우측 측두-두정엽 뇌출혈 후 발생한 교차 실어증 1예}

\section{김주연 · 장원기 $\left.\right|^{12}$ · 김원석1,2}

'분당서울대학교병원 재활의학과, ${ }^{2}$ 서울대학교 의과대학 재활의학교실

배경 및 목적: 오른손잡이에서 우반구 손상 후 실어증이 나타나는 것을 교차 실어증이라 한다. 국내에서는 처음으로 뇌동정맥기형으 로 우반구 뇌출혈 후 운동성 실어증이 나타났으나 전도성 실어증으로 실어증 유형이 변한 증례를 문헌 고찰과 함께 보고하는 바이다. 방법: 뇌동정맥기형으로 인해 우반구 측두-두정엽의 뇌출혈 후 교차 전도성 실어증이 발생한 30 대 남성 1 명의 뇌영상, 초기 언어적 특징, 실어증의 변화 양상을 8 주간 추적 관찰하여 분석하였다. 결과: 초기 PK-WAB-R에서 AQ 72, 백분위수 $64 \% \mathrm{ile,} 8$ 주 후의 평가에서 AQ 95, 백분위수 $98.9 \%$ ile로 평가되었다. 사후 평가에서의 따라 말하기 점수는 환자군에 속하였는데 따라 말하기의 오류는 음운단기기억 상의 손상이 있음을 예측할 수 있다. 본 환자는 Alexander 등의 제안에서 비정형 교차 실어증으로 진단할 수 있고, Nagaraja 등의 제안에 서는 언어능력이 양측 반구 모두에 있는 것으로 예측할 수 있다. 또한 발병 초기에 거스트만 증후군의 일부가 나타난 것을 고려하면 우 성 두정엽의 기능도 부분 교차되어 있음을 짐작할 수 있다. 논의 및 결론: 본 연구는 교차 실어증의 실어증적 변화를 초기부터 치료를 종결하는 시점까지 보고한 점, 국내의 선행연구를 문헌 고찰과 함께 제시한 점에서 의의가 있다. 추후에는 발병 초기에 종합적인 인지 검 사를 시행하여 교차 실어증의 언어적 문제와 인지 처리과정 간의 특성을 파악해 $\mathrm{CA}$ 의 임상적 특징을 분석하는 것이 필요하겠다.

핵심어: 교차 실어증, 전도성 실어증, 우반구 손상, 뇌졸중

\section{참고문헌}

*문헌 연구에 사용된 논문임.

강연욱 (2006). K-MMSE (Korean-Mini Mental State Examination)의 노인 규준 연구. 한국 심리학회지: 일반, 25(2), 1-12.

김향희 (2021). 신경언어장애. 서울: 학지사.

김향희, 나덕렬(2012). 파라다이스·한국판-웨스턴 실어증 검사(개정판). 서울: 파라다이스복지재단.

*노혁재, 김용욱, 박창일, 박종범, 장재훈 (2007). 우측 중간 대뇌 동맥 경색 후 발생한 비유창성 교차실어증(Nonfluent Crossed Aphasia) 1례. 대한재

활의학회지, 31(6), 772-775.

백신혜, 신동익, 이형석, 이성현, 이상수, 김지선 (2011). Acute aphasia after right Hemisphere stroke: a case report. 충북의대학술지, 21(1), 233-238.

*이기욱, 나상준, 염규선, 김정은, 김용덕 (2007). 우뇌 병변으로 발생한 해리성 교차언어상실증과 구어불능증 1예. 건양의대학술지, 7(1), 84-86.

*이상건, 김재우, 하경민 (1992). 오른손잡이에서의 교차 실어증 1례. 대한신경과학회지, 10(2), 219-223.

*이준균, 김종성, 권순억, 나덕렬, 손영철 (1999). 교차 실어증과 심한 좌측 편무시를 보인 우뇌반구 경색증 1례. 대한뇌졸중학회지, 1(2), 246-250.

조남순, 온석훈, 장현정, 전희정, 이강우, 김연희 (2009). 전도성 실어증을 유발하는 뇌 병소. 대한뇌신경재활학회, 2(1), 85-90.

*조용진, 박규현 (1997). 교차성 실어증 1례. 대한신경과학회지, 15(2), 382-387.

하지완, 황유미, 편성범 (2012). 다차원 구어 단기기억에 따른 전도 실어증 환자의 언어수행력 분석. 한국인지과학회, 23(4), 425-455.

×한설희 (2011). Gerstmann 증후군을 동반한 교차 실어증 1례:MRI 및 SPECT를 이용한 연구. 충북의대학술지, 11(1), 76-82.

\section{ORCID}

김주연(제1저자, 언어재활사 https://orcid.org/0000-0003-0998-5726); 장원기(공동저자, 교수 https://orcid.org/0000-0001-9756-6817);

김원석(교신저자, 교수 https://orcid.org/0000-0002-1199-5707) 